\title{
The effects of chronic whole-body vibration training on immune system of sedentary
}

\section{young women}

Os efeitos do treinamento crônico de vibração de corpo inteiro no sistema imunológico de mullheres jovens sedentárias

Los efectos del entrenamiento con vibraciones crónicas de todo el cuerpo sobre el sistema inmunológico de mujeres jóvenes sedentárias

Rogério Wagner da Silva

ORCID: https://orcid.org/0000-0002-0517-1066 Catholic University of Brasília, Brazil E-mail: rogeriows@gmail.com

Michel Kendy Souza

ORCID: https://orcid.org/0000-0001-6421-5201 Federal University of São Paulo, Brazil

E-mail: mks_gtr@hotmail.com

Thiago dos Santos Rosa

ORCID: https://orcid.org/0000-0003-0418-0945 Catholic University of Brasília, Brazil E-mail: thiagoacsdkp@yahoo.com.br

Carlos Ernesto Santos Ferreira

ORCID: https://orcid.org/0000-0003-2397-5866 Catholic University of Brasília, Brazil

E-mail: ernestobsb@gmail.com

Hugo de Luca Corrêa

ORCID: https://orcid.org/0000-0002-3080-9391 Catholic University of Brasília, Brazil

E-mail: hugo.efucb@gmail.com

Rodrigo Vanerson Passos Neves

ORCID: https://orcid.org/0000-0002-3257-7870 Catholic University of Brasília, Brazil E-mail: rpassosneves@yahoo.com.br

Jéssica Mycaelle Silva Barbosa

ORCID: https://orcid.org/0000-0002-5421-9732 Catholic University of Brasília, Brazil

E-mail: jessicamycaelle.nut@gmail.com

Leandro Lima de Sousa

ORCID: https://orcid.org/0000-0002-3990-2461 Catholic University of Brasília, Brazil E-mail: leandrolsousa08@gmail.com

Tatiana Karla dos Santos Borges ORCID: https://orcid.org/0000-0002-6813-6276

University of Brasília, Brazil

E-mail: TatianaKarla@gmail.com

Gislane Ferreira de Melo

ORCID: https://orcid.org/0000-0003-3551-5963 Catholic University of Brasília, Brazil E-mail: gmelo@p.ucb.br

Pedro Henrique Penna de Miranda Lima

ORCID: https://orcid.org/0000-0003-3617-2915 Catholic University of Brasília, Brazil E-mail: pedrohpmlima@gmail.com

Esther Agnes Pereira Lanna da Costa ORCID: https://orcid.org/0000-0003-0389-0830 Catholic University of Brasília, Brazil

E-mail: estheragnes@gmail.com

Nanci Maria de França

ORCID: https://orcid.org/0000-0002-0161-4093 Catholic University of Brasília, Brazil

E-mail: dfrancan@gmail.com 


\begin{abstract}
Objective: The aim of this study was to verify the influence of 6 weeks of whole-body vibration training on the pro- and anti-inflammatory cytokines (IL-2, IL-4, IL-6, IL-10, IFN-y e TNF- $\alpha$ ) in young, eutrophic and sedentary women. Methods: Twenty-six participants were randomly divided into two groups: Vibratory Platform Group $(\mathrm{GV}, \mathrm{n}=13)$ and Ergometry Group (GE, $\mathrm{n}=13$ ). The training program of both groups was of 20 minutes / session, 3 times per week, in non-consecutive days for 6 weeks. The load of the training was adjusted with the adapted Borg scale. GE was submitted to aerobic activity sessions in a cycle ergometer. GV was submitted to vibration platform stimulation sessions. After training program both groups were submitted to 6 weeks of detraining. Results: GV increased levels of IL-4, IL-6, IL10 and TNF- $\alpha$ after training, and it decreased all of them after detraining phase. GE increased IL2, IL-4, IL-6 and IL10 only after the detraining period. Conclusion: 6 weeks of whole-body vibration training can promote an increase in pro- and anti-inflammatory cytokines in young, eutrophic and sedentary women, however these effects seem to be transitory as the exercise is discontinued.
\end{abstract}

Keywords: Exercise; Cytokines; Immune system.

\title{
Resumo
}

Objetivo: O objetivo deste estudo foi verificar a influência de 6 semanas de treinamento vibratório de corpo inteiro nas citocinas pró e antiinflamatórias (IL-2, IL-4, IL-6, IL-10, IFN-y e TNF- $\alpha$ ) em mulheres jovens, eutróficas e sedentárias. Métodos: Vinte e seis participantes foram divididos aleatoriamente em dois grupos: Grupo Plataforma Vibratória (GV, $\mathrm{n}=13$ ) e Grupo Ergometria (GE, $\mathrm{n}=13$ ). O programa de treinamento de ambos os grupos foi de 20 minutos / sessão, 3 vezes por semana, em dias não consecutivos durante 6 semanas. A carga de treinamento foi ajustada com a escala de Borg adaptada. GE foi submetido a sessões de atividade aeróbia em cicloergômetro. O GV foi submetido a sessões de estimulação em plataforma vibratória. Após o programa de treinamento, ambos os grupos foram submetidos a 6 semanas de destreinamento. Resultados: o GV aumentou os níveis de IL-4, IL-6, IL-10 e TNF- $\alpha$ após o treinamento e diminuiu todos após a fase de destreinamento. GE aumentou IL2, IL-4, IL-6 e IL-10 somente após o período de destreinamento. Conclusão: 6 semanas de treinamento vibratório de corpo inteiro podem promover aumento de citocinas pró e antiinflamatórias em mulheres jovens, eutróficas e sedentárias, porém esses efeitos parecem ser transitórios à medida que o exercício é interrompido.

Palavras-chave: Exercício; Citocinas; Sistema imunológico.

\begin{abstract}
Resumen
Objetivo: El objetivo de este estudio fue verificar la influencia de 6 semanas de entrenamiento vibratorio de cuerpo completo sobre citocinas pro y antiinflamatorias (IL-2, IL-4, IL-6, IL-10, IFN-y y TNF). - $\alpha$ ) en mujeres jóvenes, eutróficas y sedentarias. Métodos: Veintiséis participantes fueron divididos aleatoriamente en dos grupos: Grupo de Plataforma Vibratoria $(\mathrm{GV}, \mathrm{n}=13)$ y Grupo de Ergometría $(\mathrm{GE}, \mathrm{n}=13)$. El programa de entrenamiento para ambos grupos fue de 20 minutos / sesión, 3 veces por semana, en días no consecutivos durante 6 semanas. La carga de entrenamiento se ajustó utilizando la escala de Borg adaptada. GE se sometió a sesiones de actividad aeróbica en un cicloergómetro. El GV se sometió a sesiones de estimulación en una plataforma vibratoria. Después del programa de entrenamiento, ambos grupos se sometieron a 6 semanas de desentrenamiento. Resultados: GV aumentó los niveles de IL-4, IL-6, IL-10 y TNF- $\alpha$ después del entrenamiento y disminuyó todos después de la fase de desentrenamiento. GE aumentó IL2, IL-4, IL-6 e IL-10 solo después del período de desentrenamiento. Conclusión: 6 semanas de entrenamiento vibratorio de cuerpo completo pueden promover un aumento de citocinas pro y antiinflamatorias en mujeres jóvenes, eutróficas y sedentarias, pero estos efectos parecen ser transitorios cuando se detiene el ejercicio.
\end{abstract}

Palabras clave: Ejercicio; Citoquinas; Sistema inmunológico.

\section{Introduction}

Whole-body vibration training (WBV) became popular as an alternative training model for traditional resistance training, in is characterized by a vibration stimulus during exercise that is induced by an oscillatory / vibratory platform. Specifically, the vibration exercise is based on controlled oscillations, where the vibration is transferred from a device to the human body (Martínez-Pardo, Martínez-Ruiz, Alcaraz, \& Rubio-Arias, 2015; Martínez-Pardo, Romero-Arenas, Alcaraz, \& Research, 2013). It was reported to promote some relevant physical improvements, increasing muscular activation and muscle performance in athletes, healthy and rehabilitation subjects (Morel, Marín, Moreira-Marconi, Dionello, \& Bernardo-Filho, 2018).

Recent studies suggest that WBV increase the strength of lower limb muscles induced by the magnitude of vibration (Delecluse, Roelants, Verschueren, Sports, \& Exercise, 2003; Games, Sefton, \& Wilson, 2015; Martínez-Pardo et al., 2013). Since a high magnitude of vibration can produce a greater neuromuscular activation resulting in a greater muscular development 
(Marín et al., 2012; Naghii et al., 2011). Moreover, the literature brings a variety of physiological adjustments associated with performance improvements by WBV, such as: increase in energetic metabolism (Games et al., 2015; Rittweger, Schiessl, \& Felsenberg, 2001), hormonal responses (Martínez-Pardo et al., 2015) and peripheral circulation (Games et al., 2015; Naghii et al., 2011).

Although there are many studies that presented some positive effects of WBV, meanwhile, there is a gap regarding the effects of WBV on inflammatory markers and immune system, furthermore, the limited evidence suggests that an acute WBV session can promote improvements on inflammatory markers of elderly and in individuals with fibromyalgia (Ribeiro et al., 2018; Simão et al., 2012). In this sense, Hazell, Olver, Hamilton, Lemon, and Research (2014) evaluated the acute effects of the WBV on inflammatory markers, interleukin (IL)-6 and IL-10, immediately after 4 and 24 hours after the exercise session. The authors observed an increase in IL-6 concentration only immediately after the exercise session. At this perspective, WBV shows a possible influence on the inflammatory biomarkers, therefore, it become pertinent that more studies aim to verify the chronic effects of WBV on the immune system.

Thus, the present study aimed to verify the influence of 6 weeks of WBV on the pro- and anti-inflammatory cytokines in young, eutrophic sedentary women. We hypothesized that WBV would induce a regulation on the pro- and anti-inflammatory cytokines.

\section{Methodology}

This is a quasi-randomized controlled trial (Pereira et al., 2018). All the volunteers were invited to participate via electronic message sent to all students of an university localized in the federal district. Participants were instructed not to perform any change in their routines (e.g. incidental physical activity, nutritional habits, sleeping hours, etc.), and not consume alcohol $24 \mathrm{~h}$ before sessions. Inclusion criteria: Be over 18 years-old, be sedentary (e.g. without practicing regular structured, oriented physical activity for at least 60 days before the start of the intervention procedure) and sign the Informed Consent Form. Exclusion criteria: Present conditions that could suggest limitations in the exercise sessions on vibratory platform, such as: temporary physical incapacity; pregnant or breastfeeding, osteoarticular trauma and / or absence in more than $25 \%$ of the training sessions.

The study was submitted to the Ethics Committee of the Catholic University of Brasilia (n. 020386/2015) in accordance with Resolution 466/12 of the National Health Council.

\subsection{Experimental design}

Twenty-six participants were randomly divided into two groups: Vibratory Platform Group $(\mathrm{GV}, \mathrm{n}=13)$ and Ergometry Group (GE, $n=13$ ). Before the start of the training programs, participants performed familiarization procedures on the equipment used during the study.

The protocol for both groups during the intervention period was of 18 sessions totaling $6 \mathrm{~h}$ of training ( $20 \mathrm{~min} / \mathrm{session})$, a minimum interval of $24 \mathrm{~h}$ and a maximum of $72 \mathrm{~h}$ between sessions was adopted. In order to attenuate the hormonal biases derived from the circadian variations, the training sessions were held at the same time (Gamble, Berry, Frank, \& Young, 2014). The training sessions were always monitored by the researchers, with extensive experience in this type of intervention, in order to guarantee compliance with the protocol, the safety and physical integrity of the subjects. There was no intervention in the nutritional routine.

After the intervention period, all the individuals continued to be followed for the same period, but in this second phase, without physical exercise follow-up to evaluate the effects of detraining. All volunteers were monitored weekly through a mobile 
application to ensure that they had returned to their previous sedentary lifestyle and that they did not perform any physical activity at this stage and returned to their previous routine. The organization of the study is illustrated in Figure 1, describing the procedures for selection, allocation, design and total sample loss.

Figure 1. Flow chart descriptive of the study.

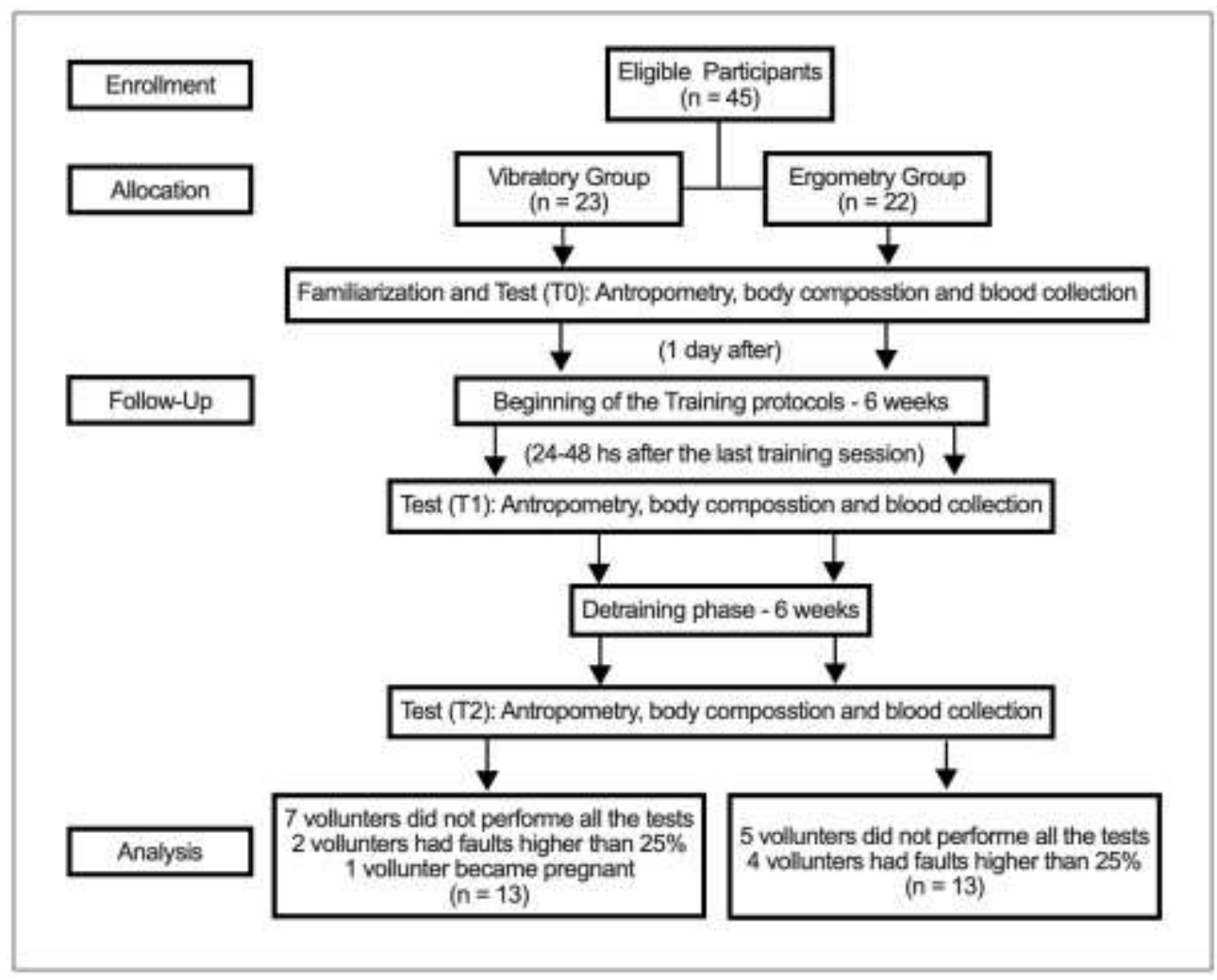

Source: Authors

\subsection{Training protocol}

GE was submitted to aerobic activity sessions in a cycle ergometer (AeroBike - R6 total exercise, Brazil), which was chosen to simultaneously stimulate both the upper and lower limbs, the training started with the load in Position 02, which applies $10.31 \mathrm{kgf}$ to the upper limbs and $9.31 \mathrm{kgf}$ for the lower limbs. The session was performed for $20 \mathrm{~min}$, with a single daily session, 3 times a week, for 6 weeks. During the training protocol, the load of the bicycles was continuously adjusted according to the subjective perception of effort reported by the adapted Borg scale (Nakamura, Moreira, \& Aoki, 2010). To ensure that the intensity was always in the range intended for the training, the researchers presented the volunteers with the scale and they indicated their sensation of effort every two minutes, if the reported perception was inferior to the classification n. 3 the load of ergometry was increased, if the report was higher than classification n. 6 the load was reduced.

The GV was submitted to vibration platform stimulation sessions (Power Plate ${ }^{\circledR}$ Pro6 Air vibrating platforms, IL, USA). This platform has two lateral handles that transmit to the upper limbs the same vibratory load applied at its base in the lower limbs. Each session had a duration of $15 \mathrm{~min}$, with a single daily session, 3 times a week, for 6 weeks. For the beginning of the exercise, each volunteer underwent five minutes of pre-warm up on a stationary bike (Monark 828 E, Sweden) without load, totaling $20 \mathrm{~min}$ of training in each session. During the study the frequencies used on the platforms were changed every two weeks $(30 \mathrm{~Hz}, 35 \mathrm{~Hz}$ and $40 \mathrm{~Hz})$ and the amplitude used was alternated weekly ( $2 \mathrm{~mm}$ and $4 \mathrm{~mm}$ ). The detailed description of the periodization of the training can be observed in Table 1. The frequency and amplitude of the vibration training were not 
changed during all the sessions, the subjective perception of effort was collected only immediately after the end of the training session (Nakamura et al., 2010).

A static initial posture was adopted during the vibration sessions, the participants remained standing on the platform with a $30^{\circ}$ of knee flexion measured with a goniometer (Cardiomed ${ }^{\circledR}$ goniometer, São Paulo, Brazil) (Santos-Lozano, SantinMedeiros, Marín, Hernández-Sánchez, \& Vallejo, 2011).

The stimulation position was standardized by placing the sagittal plane of the body over the marked point in the center of the vibratory platform base and aligning the feet at the same shoulder distance, the subject were indicated to be barefoot or to wear only socks, with the upper limbs extended along the trunk holding in the lateral handles that transmitted the vibration to the upper limbs. While the dynamic positioning started from the static position and performed the movements predicted in the training program.

\subsection{Body composition}

Fat mass and fat free mass were determined by the Dual energy radiometric absorptiometry (DXA), (GE Lunar DPXIQ densitometer machine, IL, USA) (software version 4,7e) was used in the medium mode (sample rate $5 \mathrm{~mm} / \mathrm{s}$ and ampoule current RX 750mA); the temperature of the evaluation room during the measurements remained between $18^{\circ}$ and $25^{\circ}$; all adjustments in accordance with the guidelines contained in the equipment manual. Total body weight $(\mathrm{kg})$ and height $(\mathrm{m})$ were measured barefoot and wearing appropriate clothing using an electronic scale (Filizola ${ }^{\circledR}$, Brazil) for body weight measurement and a stadiometer (SECA ${ }^{\circledR} 214$, USA) was used to measure height. The body mass index (BMI) value was calculated from the proportion of body weight in kilograms per square of height in meters obtained $\left(\mathrm{kg} / \mathrm{m}^{2}\right)$. The protocol followed was previously described by da Silva Rocca, Tirapegui, de Melo, and Ribeiro (2008).

\subsection{Evaluation of cytokines}

Blood samples were taken $24 \mathrm{~h}$ prior to the start of the intervention sessions (T0), between $24 \mathrm{~h}$ and $48 \mathrm{~h}$ after the end of protocol (T1), and 6 weeks after T2, a detraining phase (T2), all collections were performed in the morning with fasting volunteers.

For the determination of pro- and anti-inflammatory cytokines such as IL-2, IL-4, IL-6, IL-10, interferon (IFN)-y and tumor necrosis factor (TNF)- $\alpha, 5 \mathrm{~mL}$ of blood was collected by peripheral venous puncture in EDTA anticoagulant at the rate of $1.0 \mathrm{mg} / \mathrm{dL}$, the samples were centrifuged for $15 \mathrm{~min}$ at 5,000 RPM, this serum was stored at $-20^{\circ} \mathrm{C}$ and processed all at the same time, using the technique of flow cytometry (BD LSRFortessa, São Paulo, Brazil) (Givan, 2011; Nolan \& Condello, 2013; Pockley, Foulds, Oughton, Kerkvliet, \& Multhoff, 2015), the human analysis kit (BD Biosciense, San Diego, CA, USA) was used; the event counting was adopted with fully automated, high quality standard, for the identification and quantification of the samples.

\subsection{Statistical analysis}

The data are presented as mean \pm standard deviation. The Kolmogorov Smirnov and Shapiro Wilks test were applied for normality verification. Considering the non-normal distribution of cytokines concentrations were log transformed to derive a near normal distribution and a constant was added before the logarithmic transformation (da Cunha Nascimento et al., 2015). In order to verify intragroup (GV x GV, GE x GE), intergroups (GV x GE) and time (T0, T1 and T2) changes, the two-way analysis of variance was used (2-way ANOVA). The adjustment of the multiple comparisons was done through the Tukey test. In all analyzes, the significance level $p \leq 0.05$ was adopted. The analyzes were performed in SSPS (IBM SPSS software version 23.0, USA). 


\section{Results and Discussion}

Regarding the descriptive characteristics, Table 1 presents the general anthropometric data of the two groups. The results are presented with mean and standard deviation. Both groups are normal and do not present any significant differences in the descriptive measures between them.

Table 1. Body Composition and Anthropometric of volunteers

\begin{tabular}{lll}
\hline Variables & GV & GE \\
\hline Age (years) & $20.77 \pm 2.86$ & $20.62 \pm 4.35$ \\
Weight $(\mathrm{kg})$ & $58.77 \pm 9.16$ & $57.73 \pm 13.84$ \\
Height $(\mathrm{m})$ & $1.61 \pm 0.05$ & $1.64 \pm 0.06$ \\
Body Mass Index $\left(\mathrm{kg} \cdot \mathrm{m}^{-2}\right)$ & $22.72 \pm 3,67$ & $21.31 \pm 4.18$ \\
Fat-Free Body Mass $(\mathrm{kg})$ & $40.37 \pm 3.31$ & $40.26 \pm 5.78$ \\
Fat Body Mass $(\mathrm{kg})$ & $18.36 \pm 7.16$ & $17.47 \pm 8.69$ \\
\hline
\end{tabular}

No significant difference $(p>0.05)$. Abbreviations: GV - Vibratory Platform group; GE - Ergometry group. Source: Authors.

In Figure 2 is presented the pro- and anti-inflammatory markers responses, it was observed that almost all cytokines (IL-4, IL-6, IL-10 and TNF- $\alpha$ ) had the same pattern in GV group (intragroup comparison), with an increase in after training protocol (T1 vs. T0, p<0.01) and a decrease after detraining (T2 vs. T1, p<0.006); the IL-2 and IFN- $\gamma$ showed no significant difference in GV group ( $\mathrm{p}>0.05)$.

The intragroup comparison for GE group also showed a similar pattern between most of the cytokines (IL2, IL-4, IL-6 and IL-10), with a significant increase after detraining phase ( $<<0.01)$; the IL-10 was the only cytokine that also increased immediately after 6 weeks of training ( $\mathrm{p}=0.04)$; the TNF- $\alpha$ and IFN- $\gamma$ showed no significant modulation after ergometric exercise protocol ( $\mathrm{p}>0.05)$. Data presented in Figure 2.

In the intergroup comparison, we observed that IL-4, IL-6 and IL-10 showed a significant difference between training programs 6 weeks after detraining phase (T2 moment, p<0.009). Data showed in Figure 2.

The interaction between training protocol and time was observed in most of the cytokines (IL-4, IL-6, IL-10 and TNF$\alpha ; \mathrm{p}<0.005)$, but not for IL-2 and IFN-y $(\mathrm{p}>0.05)$. 
Figure 2. Blood circulating cytokines.
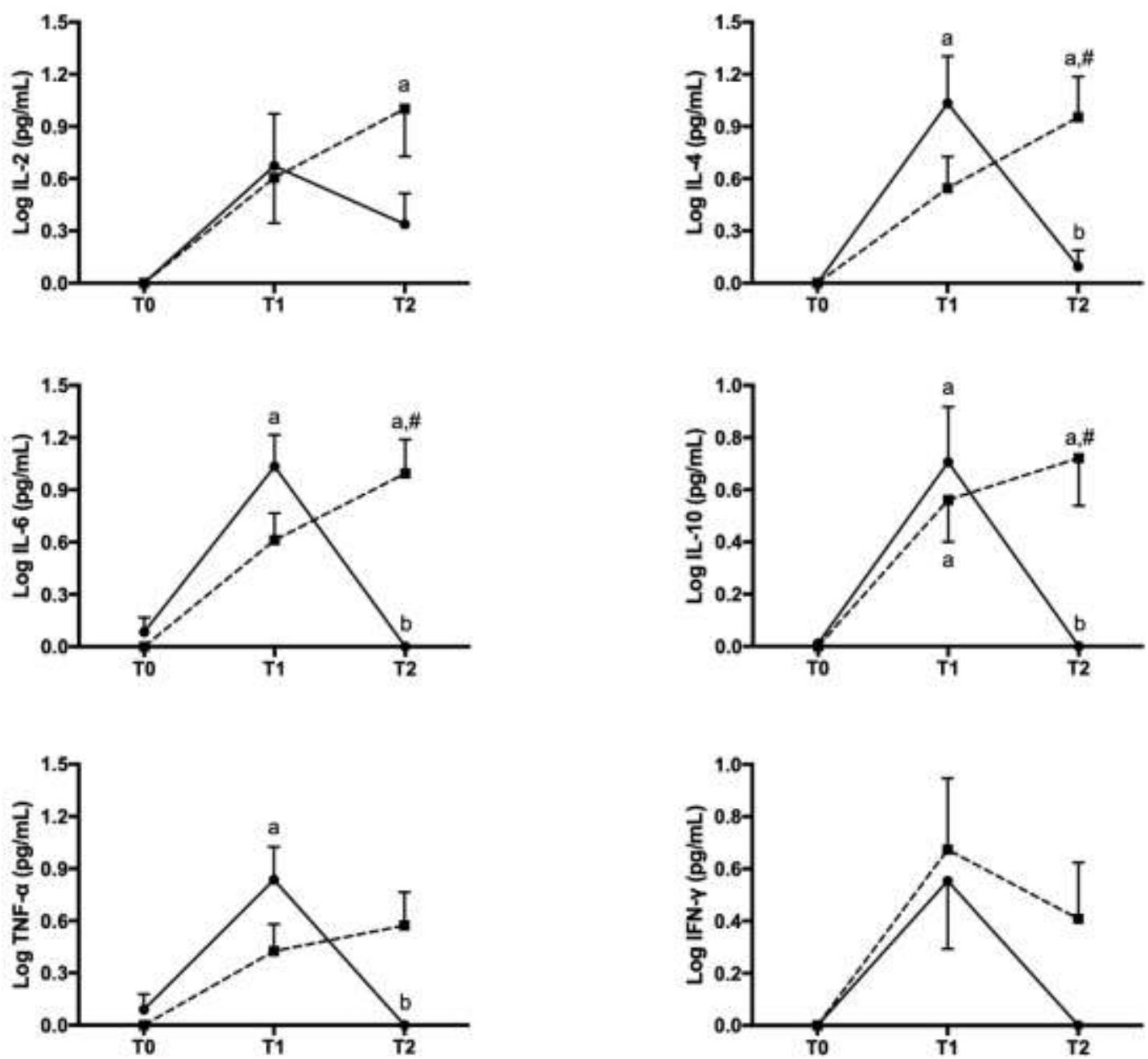

\section{GV}

\section{GE}

Legends: IL - interleukin; GV - Whole-body vibration group; GE - Ergometry Group. Data are presented as mean \pm SD. Intragroup comparison: ${ }^{\mathrm{a}} p<0.01$ vs. T0; ${ }^{\mathrm{b}} p<0.01$ vs. T1. Intergroup comparison: ${ }^{\#} \mathrm{GV} v s$. GE in the same time point, $p<0.01$. Source: Authors.

Abbreviation: IL - interleukin; GV - Whole-body vibration group; GE - Ergometry Group. Data are presented as mean \pm SD. Intragroup comparison: a p $<0.01$ vs. T0; b p <0.01 vs. T1. Intergroup comparison: \# GV vs. GE in the same time point, $\mathrm{p}<0.01$.

The present study aimed to evaluate the effects of WBV program on inflammatory markers of young, eutrophic and sedentary women. As expected, it was noticed that 6 weeks of WBV increased almost all the cytokines analyzed, except for IL2 and IFN-y, but both, also showed a tendency to increase after WBV protocol, however without sufficient levels to present significant difference. We also evaluate the effects of 6 weeks of detraining, to evaluate the inflammatory modulation after the end of the stimulus, and it was observed that all the cytokines returned to basal levels in WBV.

On the other hand, ergometric exercise had a smaller effect after 6 weeks of training when compared to WBV, however, it exhibited a higher influence on inflammatory state after the detraining phase, increasing almost all cytokines, except for INF$\mathrm{\gamma}$, demonstrating that this type of exercise initially promotes similar changes during the training period, however, it may differ significantly during the detraining period, with a slower, but more pronounced change in the circulating cytokines. 
These results suggest that both WBV and ergometric training modulates the immune system, however, with different intensities; the first one, showed a transitory effect on the pro- and anti-inflammatory cytokines, in other words, the WBV promoted a reversible adaptive process to immune system, nevertheless, the ergometric exercise had longer effects, which in an extensive analysis, it would probably promote greater adaptive process in the inflammatory modulation.

This effects is due to the fact that ergometric training generates more tissue damage due to mechanical stress, which leads to a greater production of pro-inflammatory cytokines as a product of the damage, thus stimulating the anti-inflammatory cytokines to minimize this effect (Nieman \& Pedersen, 1999).

In the study of Hazell et al. (2014), it could be observed that after a dynamic exercise session of WBV, there was an additional muscle damage, pain, and acute inflammation effect compared to the same exercise session without vibration. They found a small increase in the pro-inflammatory cytokines IL-6 and IL-1 $\beta$ after both exercises, and they also found an increase in the anti-inflammatory cytokine IL-10 after WBV exclusively, since the WBV session resulted in a larger overall response than the non-vibration session. Nevertheless, they suggest that, apparently, the exercise in WBV has little effect on inflammation.

In contrast, Cristi, Collado, Márquez, Garatachea, and Cuevas (2014) found that WBV did not alter inflammatory parameters after 9 weeks of training in health older adults, however they observed an increase in muscle strength and power in upper and lower limbs.

In addition to this, in our study, when observing the detraining period, it was noted that the GV group had a subjective perception of exertion lower than GE (3.35 vs. 4.24), and the production of cytokines has a direct relation with nociception, since the pain and the immune system influence each other (Oliveira, Sakata, Issy, Gerola, \& Salomão, 2011). Therefore, this lower perception of effort in GV group may be reflected in the behavior of the circulating cytokines, as an organism reflex.

On the other hand, GV members reported physical discomfort during the dynamic sessions, even with the subjective perception of effort lesser when compared to the GE, but both of the groups achieved the range pre-determined by the researchers between 3 and 6 of the adapted Borg scale. Only one volunteer of the GV reported back pain at the end of training session, which is probably related to a higher sensitivity to vibrations and a pre-existing inflammation in the lumbar spine, as it has been previously described by long occupational WBV exposure, such was helicopter pilots (Zeeman, Kartha, \& Winkelstein, 2016).

The present study has some limitations that should be mentioned. Firstly, it was not possible to quantify the intensity of the exercise with more precise instrument, however, the subjective effort scale is a valid and precise instrument in the control of training load and muscular pain (Borg, 2000). Another limitation is the small sample size due to the volunteer's withdrawal and lack of commitment; however, this study was the first that brings the chronic effect of WBV on pro- and anti-inflammatory cytokines compared to ergometry exercise training.

Although the limitations of the present study, it may contribute to a greater characterization of the effects of the vibratory platform on the human organism, since this is the first study that approaches its effects chronically on pro and anti-inflammatory cytokines using flow cytometry, the gold standard for the cytokine measurement. In addition, the present study collaborates with pertinent information to the WBV and immune system, since, this is the first study in the literature that compared the chronic effects of WBV with ergometric training in the immune system.

In this sense, we conclude that 6 weeks of WBV promoted an increase of pro- and anti-inflammatory cytokines on young, eutrophic and sedentary women. Furthermore, these results indicate that a WBV program can modulate the immune system, however, this effect seems to be temporary if the exercise is discontinued.

\section{Conclusion}

In this sense, we conclude that 6 weeks of WBV promoted an increase of pro- and anti-inflammatory cytokines on 
young, eutrophic and sedentary women. Furthermore, these results indicate that a WBV program can modulate the immune system, however, this effect seems to be temporary if the exercise is discontinued.

\section{Acknowledgments}

We acknowledge the National Council for Scientific and Technological Development (CNPq), the Foundation for Research Support of the Federal District (FAP-DF) for providing financial support. We also thank the representatives of Power Plate Brazil; the technical collaboration of employees in the laboratories of the Catholic University of Brasilia (UCB): Laboratory of Physical Evaluation and Training (LAFIT); Laboratory of Clinical Analysis (LAC); Laboratory of Nursing Practices (LPE); (LIG) and the Laboratory of Immunology of the University of Brasília (UNB) responsible for the measurement of cytokines.

\section{References}

Borg, G. (2000). Escalas de Borg para a dor eo esforço: percebido: Manole.

Cristi, C., Collado, P. S., Márquez, S., Garatachea, N., \& Cuevas, M. J. J. E. (2014). Whole-body vibration training increases physical fitness measures without alteration of inflammatory markers in older adults. 14(6), 611-619.

da Cunha Nascimento, D., de Sousa, N. M. F., de Sousa Neto, I. V., Tibana, R. A., de Souza, V. C., \& Vieira, D. C. L. (2015). Classification of pro-inflammatory status for interleukin-6 affects relative muscle strength in obese elderly women. 27(6), 791-797.

da Silva Rocca, S. V., Tirapegui, J., de Melo, C. M., \& Ribeiro, S. M. L. J. R. B. d. C. F. (2008). Efeito do exercício físico nos fatores de risco de doenças crônicas em mulheres obesas. 44(2), 185-192.

Delecluse, C., Roelants, M., Verschueren, S. J. M., Sports, S. i., \& Exercise. (2003). Strength increase after whole-body vibration compared with resistance training. 35(6), 1033-1041.

Gamble, K. L., Berry, R., Frank, S. J., \& Young, M. E. J. N. R. E. (2014). Circadian clock control of endocrine factors. $10(8), 466$.

Games, K. E., Sefton, J. M., \& Wilson, A. E. J. (2015). Whole-body vibration and blood flow and muscle oxygenation: a meta-analysis. $50(5)$, $542-549$.

Givan, A. L. (2011). Flow cytometry: an introduction. In Flow Cytometry Protocols (pp. 1-29): Springer.

Hazell, T. J., Olver, T. D., Hamilton, C. D., Lemon, P. W. J. T. J. o. S., \& Research, C. (2014). Addition of synchronous whole-body vibration to body mass resistive exercise causes little or no effects on muscle damage and inflammation. 28(1), 53-60.

Marín, P. J., Herrero, A. J., García-López, D., Rhea, M. R., López-Chicharro, J., González-Gallego, J., \& Research, C. (2012). Acute effects of whole-body vibration on neuromuscular responses in older individuals: implications for prescription of vibratory stimulation. 26(1), 232-239.

Martínez-Pardo, E., Martínez-Ruiz, E., Alcaraz, P. E., \& Rubio-Arias, J. A. J. N. H. (2015). Efectos de las vibraciones de cuerpo completo sobre la composición corporal y las capacidades físicas en adultos jóvenes físicamente activos. 32(5), 1949-1959.

Martínez-Pardo, E., Romero-Arenas, S., Alcaraz, P. E. J. T. J. o. S., \& Research, C. (2013). Effects of different amplitudes (high vs. low) of whole-body vibration training in active adults. 27(7), 1798-1806

Morel, D. S., Marín, P. J., Moreira-Marconi, E., Dionello, C. F., \& Bernardo-Filho, M. (2018). Can Whole-Body Vibration Exercises in Different Positions Change Muscular Activity of Upper Limbs? A Randomized Trial. 16(4), 1559325818804361. 10.1177/1559325818804361

Naghii, M., Ghanizadeh, G., Darvishi, P., Ebrahimpour, Y., Mofid, M., Torkaman, G., \& Hedayati, M. J. A. P. H. (2011). Whole body vibration is a safe exercise training method and induces no impaired alterations on rat plasma parameters. 98(4), 442-448.

Nakamura, F. Y., Moreira, A., \& Aoki, M. S. J. J. o. p. e. (2010). Monitoramento da carga de treinamento: a percepção subjetiva do esforço da sessão é um método confiável. 21(1), 1-11.

Nieman, D. C., \& Pedersen, B. K. J. S. M. (1999). Exercise and immune function. 27(2), 73-80.

Nolan, J. P., \& Condello, D. J. C. p. i. c. (2013). Spectral flow cytometry. 63(1), 1.27. 21-21.27. 13.

Oliveira, C. M. B. d., Sakata, R. K., Issy, A. M., Gerola, L. R., \& Salomão, R. J. R. b. d. a. (2011). Cytokines and pain. 61 (2), $260-265$.

Pereira, A. S., Shitsuka, D. M., Parreira, F. J., \& Shitsuka, R. (2018). Metodologia da pesquisa científica. UFSM. https://repositorio. ufsm. br/bitstream/handle/1/15824/Lic_Computacao_Metodologia-Pesquisa-Cientifica.pdf.

Pockley, A. G., Foulds, G. A., Oughton, J. A., Kerkvliet, N. I., \& Multhoff, G. J. C. p. i. t. (2015). Immune cell phenotyping using flow cytometry. 66(1), 18.18. 11-18.18. 34

Ribeiro, V., Mendonça, V., Souza, A., Fonseca, S., Camargos, A., Lage, V., \& Research, B. (2018). Inflammatory biomarkers responses after acute whole body vibration in fibromyalgia. 51(4). 
Research, Society and Development, v. 10, n. 5, e11010514377, 2021

(CC BY 4.0) | ISSN 2525-3409 | DOI: http://dx.doi.org/10.33448/rsd-v10i5.14377

Rittweger, J., Schiessl, H., \& Felsenberg, D. J. E. j. o. a. p. (2001). Oxygen uptake during whole-body vibration exercise: comparison with squatting as a slow voluntary movement. 86(2), 169-173.

Santos-Lozano, A., Santin-Medeiros, F., Marín, P. J., Hernández-Sánchez, S., \& Vallejo, N. G. J. R. R. I. d. C. d. D. d. r. (2011). Comparación entre la respuesta de la actividad muscular lumbar en plataforma vibratoria y en ejercicio clásico de squat isométrico en $30^{\circ}$ y $60^{\circ}$.(A comparison of the lumbar muscle activity responsein $30^{\circ}$ and $60^{\circ}$ isometric squat between whole-body vibration and a classic exercise). 8(27), 31-43.

Simão, A. P., Avelar, N. C., Tossige-Gomes, R., Neves, C. D., Mendonça, V. A., \& Miranda, A. S. (2012). Functional performance and inflammatory cytokines after squat exercises and whole-body vibration in elderly individuals with knee osteoarthritis. 93(10), 1692-1700.

Zeeman, M. E., Kartha, S., \& Winkelstein, B. A. J. J. o. O. R. (2016). Whole-body vibration induces pain and lumbar spinal inflammation responses in the rat that vary with the vibration profile. $34(8), 1439-1446$. 